\begin{tabular}{cc|c}
\hline Tar. Bil. Der. & Tarm Bilimleri Dergisi & Journal of Agricultural Sciences \\
& $\begin{array}{c}\text { Dergi web sayfası: } \\
\text { www.agri.ankara.edu.tr/dergi }\end{array}$ & Journal homepage: \\
& www.agri.ankara.edu.tr/journal
\end{tabular}

\title{
Resistance and Tolerance of Commercial Onion Cultivars to Stem and Bulb Nematode, Ditylenchus dipsaci
}

\section{Elif YAVUZASLANOGLU ${ }^{\mathrm{a}}$}

${ }^{a}$ Karamanoğlu Mehmetbey University, Technical Sciences Vocational School, Department of Plant and Animal Production, Karaman, TURKEY

\section{ARTICLE INFO}

Research Article

Corresponding Author: Elif YAVUZASLANOGLU, E-mail: eyavuzaslanoglu@kmu.edu.tr, Tel: +90 (535) 2340557

Received: 03 July 2018, Received in Revised Form: 06 August 2018, Accepted: 06 September 2019

\begin{abstract}
Nematode resistance and tolerance reactions of 28 onion cultivars grown commercially in Turkey to stem and bulb nematode were studied at $20{ }^{\circ} \mathrm{C}, 70 \% \mathrm{RH}$ and 16:8 h L:D photoperiod in growth chamber with 10 replications and at $27 \pm 4{ }^{\circ} \mathrm{C}$ and 16:8 $\mathrm{h} \mathrm{L}: \mathrm{D}$ photoperiod in greenhouse with 3 replications, respectively. Ditylenchus dipsaci multiplied in all cultivars tested. The lowest multiplication was determined in cv. Valenciana from Atatürk Horticultural Central Research Institute with 91 nematodes/pot and a multiplication rate of 0.5 . Plant height of cultivars were significantly different in the first tolerance experiment with having an average plant hight of 33.5 and $103.1 \mathrm{~mm}$ for inoculated and inoculated plants, respectively $(\mathrm{P}<0.05)$. Onion shoot diameter was statistically greater in nematode inoculated plants with $7.4 \mathrm{~mm}$ than inoculated plants with $6.0 \mathrm{~mm}$ in second tolerance experiment $(\mathrm{P}<0.05)$. Plant weight was not found different in both tolerance experiments with nematode inoculation. There was not any statistically difference among cultivars for plant height, plant diameter, plant weight and nematode multiplication in the experiments. Plant diameter for cv. Betapanko in first tolerance experiment and plant height for the Banko type onion in the second tolerance experiment sustained significant negative correlations with nematode numbers. Plant weight for cv. Biotek Boran in second experiment, plant height for $\mathrm{cv}$. Taraz in second experiment and, plant diameter and plant weight for cv. Taraz in first tolerance experiment sustained significant positive correlations with nematode multiplication. It could be recommended that Valenciana could lower nematode multiplication and Biotek Boran and Taraz could maintain a better plant development in nematode infested onion growing areas.
\end{abstract}

Keywords: Ditylenchus dipsaci; Stem and bulb nematode; Onion; Resistance; Tolerance

(C) Ankara Üniversitesi Ziraat Fakültesi

\section{Introduction}

Ditylenchus dipsaci originally described from Dipsacus fullonum (Kühn 1857). It has 30 biological races on more than 500 hosts (Sturhan \& Brzeski 1991).

The onion race of $D$. dipsaci has a wide host range, though it mostly infects onion, garlic, pea and bean (Janssen 1994). Control of the nematode using host crop rotation under field conditions is difficult due to the variation in host preferences of different races. Because of the environmental concerns; use of the nematicides is not preferable and economical under field conditions. There are no registered nematicides for $D$. dipsaci control in onion in Turkey. Dipping onion bulbs in hot water 
at $44-45{ }^{\circ} \mathrm{C}$ for $3 \mathrm{~h}$ before sowing provides a level of control the nematode (Bridge \& Hunt 1986). Early sowing of onion plants were shown to decrease the nematode population and plant damage (Mennan 2005).

Resistance to nematodes is defined as a genetic mechanism of plant to prevent nematode infection and/or reproduction. Besides, tolerant plants provides high yield under nematode multiplication (Cook \& Evans 1987). Both mechanisms are useful for producers in nematode infested areas. Bergquist \& Riedei (1972) reported lack of any available resistance source of onion to D. dipsaci. However, there is some hope of some results providing lower nematode multiplication under field conditions (Yavuzaslanoglu et al 2015). Some resistant oat, rye, bean and clover (Plowright et al 2002) showed some advantages in crop rotations given the nematodes wider host range. Yet, there are no studies reporting the tolerance of onion cultivars to D. dipsaci.

Aim of this study was to investigate resistance and tolerance reactions of some onion cultivars grown commercially in Turkey to $D$. dipsaci under controlled growth chamber and greenhouse conditions.

\section{Material and Methods}

\subsection{Plant material and nematode source}

Onion cultivars were provided by commercial seed suppliers in Turkey and Atatürk Horticultural Central Research Institute (AHCRI), Yalova, Turkey. Total of 28 cultivars were tested for $D$. dipsaci resistance a in growth chamber and for tolerance in a greenhouse. The population of Ditylenchus dipsaci used was originally collected from garlic in Karaman Province (N: 37.111592, E: 33.112628), Turkey. The nematodes were cultured on sterile carrot discs (Kühnhold et al 2006) and extracted in tap water.

\subsection{Growth chamber experiments}

The experiments were conducted in a growth chamber at $20{ }^{\circ} \mathrm{C}, 70 \% \mathrm{RH}$ and 16:8 h L:D photoperiod. Plants were grown in $7 \times 8 \mathrm{~cm}$ diameter plastic pots containing a mixture of sterile sand, field soil and organic matter (45: 45: 10 by weight) and watered as needed. Ten replicates were used for each cultivar tested being totally 280 plant.

An inoculum of 200 nematodes in $10 \mu \mathrm{L}$ of $1 \%$ carboxymethylcellulose (Kühnhold et al 2006) was applied between two leaves of each onion plant at 4-5 weeks old. The plants were grown for 6 weeks after inoculation. The nematodes were extracted from the plants overnight (Hallmann \& Subbotin 2018) and counted. Nematode multiplication rate was calculated dividing the final number by 200 , i.e. the number applied per plant.

\subsection{Greenhouse experiments}

Greenhouse experiment was conducted with same set of cultivars used in the growth chamber evaluations. The tolerance testing in the greenhouse consisted of three replicates in $7 \times 8 \mathrm{~cm}$ plastic pots using $70 \%$ and $30 \%$ sand and field soil respectively. Organic liquid fertilizer (Biovin, Konya Şeker, Konya, Turkey) with a ratio of $0.6 \mathrm{~mL} \mathrm{ha}^{-1}$ was applied one week after planting. The onions were planted on 14 April 2017 and harvested on 4 September 2017 as two sets of the material. The temperature in the greenhouse was $27 \pm 4{ }^{\circ} \mathrm{C}$ during experiment. Nematodes were applied (200 nematodes in $1 \mathrm{~mL}$ tap water) into soil around the plant in each pot 5 weeks following planting. Plant height, plant diameter and fresh weight were recorded at the end of the experiment. Nematodes were extracted and counted from the plant and soil from each pot (Hallmann \& Subbotin 2018).

\subsection{Statistical analysis}

Data on plants and nematodes for each cultivar was analyzed using ANOVA and LSDs calculated using all pairs Tukey's HSD test. Plant height, plant diameter, plant weight and nematode numbers for each cultivar in the study was compared using multivariate test. Statistical analyses were applied using JUMP 5.0.1a. Program (JMP 2009). 


\section{Results and Discussion}

\subsection{Growth chamber experiments}

There were significant differences $(\mathrm{P}<0.05)$ in the nematode multiplication rates of the cultivars tested. Cultivars fell into four LSD groups (Table 1). The lowest nematode multiplication was in cv. Valenciana ex AHCRI with mean of 91 nematodes/ plant (range 0-600) and multiplication rate of 0.5 (0-3). Other cultivars with low multiplication rates were Burgaz10 ex MTN Seed, Kantartopu, Naz, Seyhan, Panko, Banko type onion, Aki, Gence, Akgün12, Sampiyon, Hazar, Banka, Early White Grano and Valenciana ex MTN Seed with 216-776 nematodes/plant and multiplication rates of 1-3.8 (Table 1).

Table 1- Plant material and their origin and times tested with nematode numbers multiplied and multiplication rate $(\mathrm{MR})$ in the resistance experiment

\begin{tabular}{|c|c|c|c|c|c|}
\hline Genotype & Origin & $\begin{array}{c}\text { Times } \\
\text { screened }\end{array}$ & D. dipsaci plant ${ }^{1}$ & $M R$ & $\begin{array}{c}\text { LSD } \\
\text { Group }\end{array}$ \\
\hline Kantartopu & AHCRI & 2 & $272 \pm 833(0-1280)$ & $1.3 \pm 4.1(0-6.4)$ & $\mathrm{c}$ \\
\hline Betapanko & AHCRI & 4 & $1108 \pm 493(0-14900)$ & $5.5 \pm 2.4(0-74.5)$ & $\mathrm{c}$ \\
\hline Valenciana & AHCRI & 2 & $91 \pm 833(0-600)$ & $0.5 \pm 4.1(0-3.0)$ & $\mathrm{c}$ \\
\hline Pan88 & AHCRI & 3 & $1038 \pm 589(0-8980)$ & $5.2 \pm 2.9(0-44.9)$ & $\mathrm{c}$ \\
\hline Akgün12 & AHCRI & 1 & $424 \pm 949(0-1960)$ & $2.1 \pm 4.7(0-9.8)$ & $\mathrm{c}$ \\
\hline Banka & KUCUK CIFTLIK SEED ${ }^{\circ}$ & 2 & $618 \pm 802(0-4120)$ & $3.1 \pm 4.0(0-20.6)$ & $\mathrm{c}$ \\
\hline Daytona & INTFA AGRICULTURE $^{\odot}$ & 2 & $1606 \pm 802(0-8580)$ & $8.0 \pm 4.0(0-42.9)$ & bc \\
\hline Banko type onion & INTFA AGRICULTURE $^{\odot}$ & 1 & $374 \pm 949(0-3460)$ & $1.9 \pm 4.7(0-17.3)$ & $\mathrm{c}$ \\
\hline Panko & INTFA AGRICULTURE $^{\complement}$ & 1 & $364 \pm 949(0-2520)$ & $1.8 \pm 4.7(0-12.6)$ & $\mathrm{c}$ \\
\hline Safa Karbeyazi & INTFA AGRICULTURE $^{\odot}$ & 2 & $1018 \pm 905(0-6580)$ & $5.1 \pm 4.5(0-32.9)$ & bc \\
\hline Biotek Boran & INTFA AGRICULTURE $^{\circ}$ & 1 & $836 \pm 949(0-2420)$ & $4.2 \pm 4.7(0-12.1)$ & $\mathrm{bc}$ \\
\hline Aki & INTFA AGRICULTURE $^{\odot}$ & 2 & $383 \pm 802(0-3020)$ & $1.9 \pm 4.0(0-15.1)$ & $\mathrm{c}$ \\
\hline Beyaz Bilek & INTFA AGRICULTURE ${ }^{\odot}$ & 2 & $2954 \pm 802(0-21660)$ & $14.8 \pm 4.0(0-8.6)$ & $\mathrm{bc}$ \\
\hline Ersoy & INTFA AGRICULTURE ${ }^{\odot}$ & 1 & $744 \pm 949(0-3260)$ & $3.7 \pm 4.7(0-16.3)$ & $\mathrm{bc}$ \\
\hline Seyhan & MTN SEED ${ }^{\circ}$ & 1 & $292 \pm 949(0-1940)$ & $1.5 \pm 4.7(0-9.7)$ & $\mathrm{c}$ \\
\hline Hazar & MTN SEED ${ }^{\circ}$ & 2 & $586 \pm 802(0-7560)$ & $2.9 \pm 4.0(0-37.8)$ & $\mathrm{c}$ \\
\hline Metan88 & MTN SEED ${ }^{\circ}$ & 2 & $951 \pm 802(0-4560)$ & $4.8 \pm 4.0(0-22.8)$ & bc \\
\hline Burgaz10 & MTN SEED $^{\circ}$ & 1 & $216 \pm 949(0-1040)$ & $1.1 \pm 4.7(0-5.2)$ & $\mathrm{c}$ \\
\hline Karbeyazi & MTN SEED $^{\circ}$ & 2 & $1412 \pm 867(0-15340)$ & $7.1 \pm 4.3(0-76.7)$ & $\mathrm{bc}$ \\
\hline Valenciana & MTN SEED ${ }^{\circ}$ & 2 & $776 \pm 802(0-3460)$ & $3.9 \pm 4.0(0-17.3)$ & $\mathrm{c}$ \\
\hline Gence & MTN SEED ${ }^{\circ}$ & 1 & $416 \pm 949(0-1920)$ & $2.1 \pm 4.7(0-9.6)$ & $\mathrm{c}$ \\
\hline Taraz & MTN SEED ${ }^{\circ}$ & 2 & $1130 \pm 802(0-7840)$ & $5.7 \pm 4.0(0-39.2)$ & bc \\
\hline MT300 & MTN SEED ${ }^{\circ}$ & 2 & $2006 \pm 802(0-23580)$ & $10.1 \pm 4.0(0-117.9)$ & bc \\
\hline Sampiyon & MTN SEED $^{\circ}$ & 1 & $424 \pm 949(0-2680)$ & $2.1 \pm 4.7(0-13.4)$ & $\mathrm{c}$ \\
\hline Early White Grano & MTN SEED ${ }^{\circ}$ & 1 & $624 \pm 949(0-2620)$ & $3.1 \pm 4.7(0-13.1)$ & $\mathrm{c}$ \\
\hline $\mathrm{Naz}$ & MTN SEED ${ }^{\circ}$ & 2 & $283 \pm 802(0-2160)$ & $1.4 \pm 4.0(0-10.8)$ & $\mathrm{c}$ \\
\hline Balkan & BALIKESIR SEED ${ }^{\circ}$ & 1 & $7330 \pm 1501(0-4720)$ & $36.7 \pm 7.5(0-123.6)$ & $\mathrm{ab}$ \\
\hline Burgaz10 & PASA SEED ${ }^{\circ}$ & 1 & $13650 \pm 1501(0-26800)$ & $68.3 \pm 7.5(0-134.0)$ & $\mathrm{a}$ \\
\hline
\end{tabular}

Standard error was given as \pm of mean, range of nematode numbers and multiplication rate was given in parenthesis. AHCRI, Atatürk Horticulture Central Research Institute, Yalova, Turkey; MTN Seed, Balıkesir, Turkey; Küçük Çiftlik Seed, Balıkesir, Turkey; İntfa Agriculture, Konya, Turkey; Balıkesir Seed, Balıkesir, Turkey; Paşa Seed, Balıkesir, Turkey 
Mean nematode numbers of cvs Pan88 and Betapanko used for comparison were 1038 and 1108 nematodes/plant and multiplication rates of 5.2 and 5.5 , respectively, and were included in the c LSD group.

Moderate nematode multiplication rates were found in cvs Ersoy, Biotek Boran, Metan88, Safa Karbeyazi, Taraz, Daytona, MT300 and Beyaz Bilek. These were included in the bc LSD group with multiplication rates of 3.7-14.8 (i.e., 744-2954 nematodes plant $\left.{ }^{-1}\right)$. High multiplication rates were found in cvs Balkan and Burgaz10 ex Pasa Seed, 36.7 and 68.3 (7330 and 13650 nematodes plant $^{-1}$ ), respectively, and were included in the ab and a LSD groups.

Resistance studies for D. dipsaci are limited, possibility due to the wide range host of $D$. dipsaci, and resistance studies are mostly for commercial crops of the countries where this nematode is problem. Toynbee-Clarke \& Bond (1970), Griffin \& Waite (1971), Kühnhold et al (2006) and Mwaura et al (2015) conducted resistance testing studies on red clover, alfalfa, sugar beet and potato, respectively.

Onion has a large genome over which many repeats distributed (Fajkus et al 2016). It is difficult to identify resistance, and undertake resistance breeding onion, due to the complex nature of its genome and external pollination characteristics.

Pang et al (2009) identified cultivars resistant to Pratylenchus penetrans and Meloidogyne hapla among onions grown in Idaho. In the current study, none of the onion cultivars tested was completely resistant to D. dipsaci. However, low nematode multiplication was observed with cv. Valenciana from both AHCRI and MTN Seed, and some other cultivars. This is consistent with the degree of resistance already shown for cv. Valenciana ex AHCRI under field conditions by Yavuzaslanoglu et al (2015). Ogbuji (1979) conducted studies on onions with different skin color to determine D. dipsaci penetration rate. Lower nematode penetration and bloating in red skinned onion was recorded in both greenhouse and field studies. Given that $\mathrm{cv}$. Valenciana has red skin, the findings of Ogbuji (1979) are consistent with those of the current study.

\subsection{Greenhouse experiments}

Plant height, plant diameter and weight were statistically significantly different between the two experiments. Therefore the data from the two experiments were analyzed separately. Mean plant height was $67.4 \mathrm{~mm}$ in the first experiment, and 40.0 $\mathrm{mm}$ in the second experiment. Plant diameter and weight was $5.8 \mathrm{~mm}$ and $0.31 \mathrm{~g}, 6.7 \mathrm{~mm}$ and $0.44 \mathrm{~g}$ for the first and second experiment respectively. While plant height was higher in the first experiment, plant diameter and weight was lower than in the second experiment. Mean nematodes pot ${ }^{-1}$ was 18 in the first experiment, and 110 in the second experiment (inoculated plants only), with mean multiplication rates of 0.008 and 0.6 , respectively (Table 2, 3).

Mean plant height was significantly different between nematode inoculated and uninoculated plants in the first experiment; mean plant height was $34.0 \mathrm{~mm}(10.0-55.0 \mathrm{~mm})$ in nematode inoculated plants, and $103.1 \mathrm{~mm}(30.0-180.0 \mathrm{~mm})$ in uninoculated plants. There was not any statistical difference in the second experiment (Table 2, 3).

Plant diameter was not affected by nematodes in first experiment but it was significantly differed in the second experiment where it was observed a mean of $7.4 \mathrm{~mm}(1.0-15 \mathrm{~mm})$ with inoculation and $6.0 \mathrm{~mm}(1.0-15 \mathrm{~mm})$ without inoculation $(\mathrm{P}<0.05)$. Plant weight was not significantly different by nematode treatment in both experiments. There was no difference among cultivars by nematode treatment for plant height, diameter and weight in both experiments (Table 2, 3).

Plant height, plant diameter and plant fresh weight was used for tolerance evaluation in this study. Pang et al (2009) used plant dry weight and Ibrahim (2010) used plant height, number of leaves and bulb weight for evaluation onion yield. Islam et al (2007) reported a positive correlation between onion plant growth parameters including plant height, number of leaves and plant weight and bulb yield to evaluate tolerance under greenhouse conditions. 
Table 2- Plant height $(\mathrm{mm})$, plant diameter $(\mathrm{mm})$, plant weight $(\mathrm{g})$ and nematode numbers in first greenhouse tolerance experiment

\begin{tabular}{|c|c|c|c|c|c|c|c|c|c|}
\hline \multirow{2}{*}{ Cultivar } & \multirow{2}{*}{ Origin } & \multicolumn{2}{|c|}{ Plant height } & \multicolumn{2}{|c|}{ Plant diameter } & \multicolumn{2}{|c|}{ Plant weight } & \multicolumn{2}{|c|}{ D. dipsaci } \\
\hline & & + & - & + & - & + & - & + & - \\
\hline Kantartopu & AHCRI & 40.3 & 105.0 & 8.3 & 4.7 & 0.69 & 0.39 & 13.0 & 0.0 \\
\hline Betapanko & MTN seed & 29.0 & 106.7 & 5.0 & 7.0 & 0.24 & 0.15 & 27.0 & 0.0 \\
\hline Valenciana & AHCRI & 30.3 & 103.3 & 4.3 & 5.7 & 0.13 & 0.17 & 40.0 & 0.0 \\
\hline Pan88 & MTN seed & 20.7 & 70.0 & 2.0 & 5.0 & 0.03 & 0.08 & 0.0 & 0.0 \\
\hline Akgün12 & MTN seed & 33.3 & 140.0 & 5.0 & 7.7 & 0.30 & 0.58 & 27.0 & 0.0 \\
\hline Banka & İntfa agriculture & 39.3 & 81.7 & 5.7 & 5.7 & 0.34 & 0.12 & 7.0 & 0.0 \\
\hline Daytona & İntfa agriculture & 34.3 & 85.0 & 4.0 & 5.7 & 0.09 & 0.16 & 13.0 & 0.0 \\
\hline Banko type onion & İntfa agriculture & 21.7 & 125.0 & 3.7 & 7.0 & 0.06 & 0.61 & 00 & 0.0 \\
\hline Panko & MTN seed & 35.3 & 96.7 & 5.3 & 4.0 & 0.16 & 0.16 & 0.0 & 0.0 \\
\hline Safa Karbeyazi & MTN seed & 39.0 & 105.0 & 5.6 & 8.0 & 0.31 & 0.22 & 13.0 & 0.0 \\
\hline Biotek Boran & AHCRI & 32.0 & 111.7 & 6.0 & 6.0 & 0.19 & 0.29 & 40.0 & 0.0 \\
\hline Aki & MTN seed & 36.5 & 123.3 & 6.0 & 5.7 & 0.31 & 0.37 & 50.0 & 0.0 \\
\hline Beyaz Bilek & Küçük Ciftlik seed & 33.7 & 123.5 & 6.3 & 4.0 & 0.55 & 0.29 & 0.0 & 0.0 \\
\hline Ersoy & MTN seed & 29.7 & 136.7 & 9.3 & 5.0 & 0.87 & 0.43 & 0.0 & 0.0 \\
\hline Seyhan & İntfa agriculture & 32.3 & 75.0 & 7.3 & 6.0 & 0.45 & 0.60 & 13.0 & 0.0 \\
\hline Hazar & MTN seed & 41.3 & 133.3 & 9.3 & 7.3 & 0.95 & 1.13 & 13.0 & 0.0 \\
\hline Metan 88 & İntfa agriculture & 40.0 & 86.7 & 10.7 & 6.3 & 0.43 & 0.47 & 13.0 & 0.0 \\
\hline Burgaz10 & MTN seed & 33.7 & 110.0 & 5.3 & 5.0 & 0.23 & 0.29 & 0.0 & 0.0 \\
\hline Karbeyazi & İntfa agriculture & 25.5 & 78.3 & 6.3 & 5.7 & 0.10 & 0.27 & 40.0 & 0.0 \\
\hline Valenciana & AHCRI & 24.7 & 105.0 & 2.5 & 4.5 & 0.08 & 0.07 & 47.0 & 0.0 \\
\hline Gence & AHCRI & 40.7 & 86.7 & 6.0 & 6.3 & 0.21 & 0.30 & 0.0 & 0.0 \\
\hline Taraz & MTN seed & 31.3 & 65.0 & 7.0 & 4.7 & 0.22 & 0.06 & 40.0 & 0.0 \\
\hline MT300 & MTN seed & 27.0 & 96.7 & 4.7 & 4.3 & 0.10 & 0.24 & 40.0 & 0.0 \\
\hline Sampiyon & İntfa agriculture & 38.0 & 116.7 & 5.7 & 6.3 & 0.22 & 0.40 & 0.0 & 0.0 \\
\hline Early White Grano & MTN seed & 33.3 & 165.0 & 6.3 & 8.0 & 0.40 & 0.30 & 0.0 & 0.0 \\
\hline $\mathrm{Naz}$ & İntfa agriculture & 36.7 & 84.0 & 7.7 & 2.7 & 0.38 & 0.14 & 7.0 & 0.0 \\
\hline Balkan & Balıkesir seed & 39.5 & 102.7 & 7.5 & 5.3 & 0.32 & 0.25 & 70.0 & 0.0 \\
\hline Burgaz10 & Paşa seed & 39.0 & 140.0 & 7.0 & 7.0 & 0.48 & 0.07 & 27.0 & 0.0 \\
\hline
\end{tabular}

(+; nematode inoculated, -; nematode un inoculated); AHCRI, Atatürk Horticulture Central Research Institute, Yalova, Turkey; MTN seed, Balıkesir, Turkey; Küçük Çiftlik seed, Balıkesir, Turkey; İntfa agriculture, Konya, Turkey; Balıkesir seed, Balıkesir, Turkey; Paşa seed, Balıkesir, Turkey

The common symptoms of the stem and bulb nematode infection are swelling of the plant tissue and misshapen, dwarf plants (Sikora \& Fernandez 2005). In the tolerance experiment, symptoms of nematode infection were observed and associated with significantly reduced plant height and enlarged plant diameter.

For cv. Betapanko in the first experiment, there was a statistically significantly negative correlation between nematode number and plant diameter $(\mathrm{P}<0.05, \mathrm{R}=-0.82)$, with plant diameter reduced $2.0 \mathrm{~mm}$ by nematode inoculation. There was no significant trend for the other plant parameters.

For cv. Banko type onion in the second experiment, there was as significantly negative correlation between nematode numbers and plant height $(\mathrm{P}<0.05, \mathrm{R}=0.81)$, with plant height reduced $5.7 \mathrm{~mm}$ by nematode inoculation. 
Table 3- Plant height $(\mathrm{mm})$, plant diameter $(\mathrm{mm})$, plant weight $(\mathrm{g})$ and nematode numbers in second greenhouse tolerance experiment

\begin{tabular}{|c|c|c|c|c|c|c|c|c|c|}
\hline \multirow{2}{*}{ Cultivar } & \multirow{2}{*}{ Origin } & \multicolumn{2}{|c|}{ Plant height } & \multicolumn{2}{|c|}{ Plant diameter } & \multicolumn{2}{|c|}{ Plant weight } & \multicolumn{2}{|c|}{ D. dipsaci } \\
\hline & & + & - & + & - & + & - & + & - \\
\hline Kantartopu & AHCRI & 48.5 & 45.0 & 11.0 & 4.5 & 1.05 & 0.33 & 120.0 & 0.0 \\
\hline Betapanko & MTN seed & 42.0 & 43.0 & 5.7 & 5.3 & 0.22 & 0.25 & 80.0 & 0.0 \\
\hline Valenciana & AHCRI & 37.0 & 48.7 & 5.0 & 4.7 & 0.11 & 0.26 & 240.0 & 0.0 \\
\hline Pan88 & MTN seed & 26.0 & 38.5 & 4.0 & 2.5 & 0.14 & 0.09 & 80.0 & 0.0 \\
\hline Akgün12 & MTN seed & 41.7 & 48.0 & 7.3 & 4.0 & 0.38 & 0.13 & 120.0 & 0.0 \\
\hline Banka & İntfa agriculture & 38.0 & 43.3 & 7.0 & 6.0 & 0.31 & 0.26 & 180.0 & 0.0 \\
\hline Daytona & İntfa agriculture & 30.0 & 42.0 & 5.0 & 7.0 & 0.25 & 0.70 & 100.0 & 0.0 \\
\hline Banko type onion & İntfa agriculture & 31.7 & 37.3 & 5.0 & 5.0 & 0.13 & 0.21 & 27.0 & 0.0 \\
\hline Panko & MTN seed & 42.5 & 47.5 & 8.0 & 5.0 & 0.55 & 0.27 & 180.0 & 0.0 \\
\hline Safa Karbeyazi & MTN seed & 43.0 & 44.0 & 7.7 & 5.3 & 0.41 & 0.25 & 80.0 & 0.0 \\
\hline Biotek Boran & AHCRI & 37.7 & 40.3 & 7.3 & 5.0 & 0.42 & 0.19 & 113.0 & 0.0 \\
\hline Aki & MTN seed & 35.0 & - & 7.0 & - & 0.42 & - & 73.0 & 0.0 \\
\hline Beyaz Bilek & Küçük Ciftlik seed & 38.0 & 32.0 & 9.0 & 5.5 & 0.84 & 0.41 & 30.0 & 0.0 \\
\hline Ersoy & MTN seed & 40.0 & 34.0 & 10.0 & 9.0 & 0.74 & 0.65 & 20.0 & 0.0 \\
\hline Seyhan & İntfa agriculture & 38.3 & 19.5 & 7.3 & 4.0 & 0.35 & 0.03 & 147.0 & 0.0 \\
\hline Hazar & MTN seed & 32.0 & 39.3 & 6.5 & 3.0 & 0.59 & 0.16 & 200.0 & 0.0 \\
\hline Metan88 & İntfa agriculture & 38.5 & 33.0 & 5.5 & 6.0 & 0.10 & 0.39 & 150.0 & 0.0 \\
\hline Burgaz10 & MTN seed & 30.3 & 39.0 & 3.0 & 3.5 & 0.07 & 0.11 & 213.0 & 0.0 \\
\hline Karbeyazi & İntfa agriculture & - & 33.5 & - & 9.0 & - & 0.79 & - & 0.0 \\
\hline Valenciana & AHCRI & 42.3 & 39.3 & 6.7 & 7.3 & 0.42 & 0.50 & 80.0 & 0.0 \\
\hline Gence & AHCRI & 41.3 & 39.7 & 7.7 & 7.3 & 0.38 & 0.51 & 73.0 & 0.0 \\
\hline Taraz & MTN seed & 46.7 & 32.0 & 9.0 & 8.0 & 0.68 & 0.58 & 167.0 & 0.0 \\
\hline MT300 & MTN seed & 45.0 & 38.0 & 5.7 & 7.5 & 0.47 & 0.57 & 140.0 & 0.0 \\
\hline Sampiyon & İntfa agriculture & 55.5 & 51.0 & 10.0 & 8.0 & 1.12 & 0.72 & 110.0 & 0.0 \\
\hline Early White Grano & MTN seed & 39.7 & 44.0 & 10.7 & 9.5 & 1.36 & 0.86 & 73.0 & 0.0 \\
\hline $\mathrm{Naz}$ & İntfa agriculture & 43.7 & 35.5 & 8.3 & 8.5 & 0.66 & 0.38 & 47.0 & 0.0 \\
\hline Balkan & Balıkesir seed & 53.0 & 42.0 & 10.3 & 5.0 & 0.58 & 0.11 & 107.0 & 0.0 \\
\hline Burgaz10 & Paşa seed & 46.0 & 39.5 & 9.0 & 7.5 & 0.94 & 0.54 & 230.0 & 0.0 \\
\hline
\end{tabular}

(+; nematode inoculated, -; nematode un inoculated). AHCRI, Atatürk Horticulture Central Research Institute, Yalova, Turkey; MTN seed, Balıkesir, Turkey; Küçük Çiftlik seed, Balıkesir, Turkey; İntfa agriculture, Konya, Turkey; Balıkesir seed, Balıkesir, Turkey; Paşa seed, Balıkesir, Turkey

For cv. Taraz there were significant positive correlations between nematode numbers and plant height $(\mathrm{P}<0.05, \mathrm{R}=0.98)$ in the second experiment and between nematode numbers and plant diameter $(\mathrm{P}<0.05, \mathrm{R}=0.90)$ and weight $(\mathrm{P}<0.05, \mathrm{R}=0.98)$ in the first experiment. Plant height, diameter and weight increased $14.7 \mathrm{~mm}, 2.3 \mathrm{~mm}$ and $0.16 \mathrm{~g}$ with nematode inoculation, respectively (Table 2,3 ).

For cv. Biotek Boran, in the second experiment, there was a statistically significantly positive correlation between nematode numbers and plant weight $(\mathrm{P}<0.05, \mathrm{R}=0.79)$, with plant weight increased $0.22 \mathrm{~g}$ by nematode inoculation.

Significant relationship between nematode numbers and plant growth indicated that plant yield could be affected by nematode inoculation. Significant relationship between nematode numbers and plant growth were found for cvs Betapanko, Banko type onion, Taraz and Biotek Boran. While cvs Betapanko and Banko plant growth parameters 
showed negative correlation to nematode numbers, plant growth in cvs Taraz and Biotek Boran was positively correlated to nematode numbers. Increased plant yield with increasing nematode numbers is considered to be an indicator of tolerance (Trudgill 1991).

A negative relationship between cv. Betapanko bulb yield and initial nematode populations was found under field conditions by Yavuzaslanoglu et al (2015), indicating the intolerance of this cultivar and its bulb yield decreased by up to $13 \%$ with nematicide treatment, which is consistent with the findings of the current study.

\section{Conclusions}

The main outcome of the study was that $\mathrm{cv}$. Valenciana lowered $D$. dipsaci multiplication and the susceptible cultivars, Taraz and Biotek Boran, tolerated nematode infection with strong plant growth.

Results provide practical and ecologically friendly control option to growers by planting suitable cultivars in the nematode infested areas.

\section{Acknowledgements}

Turkish Scientific and Technical Research Council (Project number: 1110222) supported the study financially and commercial firms and Atatürk Horticultural Research Institute, Yalova, Turkey provided seed for the study.

\section{References}

Bergquist R R \& Riedei R M (1972). Screening of onion (Allium cepa) in a controlled environment for resistance to D. dipsaci. Plant Disease Reporter 56: 329-331

Bridge J \& Hunt D (1986). Nematodes. In: Tropical Development and Research Institute and Office of Overseas Development Administration Pest Control in Tropical Onion, Tropical Development and Research Institute, London, pp. 65-77

Cook R \& Evans K (1987). Resistance and tolerance In: Brown R H \& Kerry B R (Eds.), Principles and
Practice of Nematode Control in Crops, Academic Press, Sydney, pp. 179-231

Fajkus P, Peska V, Sitova Z, Fulneckova J, Dvorackova M, Gogela R, Sykorova E, Hapala J \& Fajkus J (2016). Allium telomeres unmasked: the unusual telomeric sequence (CTCGGTTATGGG) is synthesized by telomerase. The Plant Journal 85: 337-347

Griffin G D \& Waite W W (1971). Attraction of Ditylenchus dipsaci and Meloidogyne hapla by resistant and susceptible Alfalfa seedling. Journal of Nematology 3(3): 215-219

Hallmann J \& Subbotin S A (2018). Methods for Extraction, Processing and Detection of Plant and Soil Nematodes. In: Sikora R A, Coyne D, Hallmann J \& Timper P (Eds.), Plant Parasitic Nematodes in Subtropical and Tropical Agriculture, $3^{\text {rd }}$ Edition, CABI Publishing, Wallingford, UK, pp. 87-119

Ibrahim N D (2010). Growth and yield of onion (Allium cepa L.) in Sokoto, Nigeria. Agriculture and Biology Journal of North America 1: 556-564

Islam M K, Alam M F \& Islam A K M R (2007). Growth and yield response of onion (Allium cepa $\mathrm{L}$.) genotypes to different levels of fertilizers. Journal of Botany 36: 36-37

Janssen G J W (1994). The relevance of races in Ditylenchus dipsaci (Kühn) Filipjev, the stem nematode. Fundamentals of Applied Nematology 17(5): 469-473

JMP (2009). Statistics and Graphics Guide, Cary, NC, USA, SAS Institute Inc.

Kühn J (1857). Über das vorkommen von Anguillulen in erkrankten Blüthenköpfen von Dipsacus fullonum L. Zeitschr. wissenschaftl. Zoologie 9: 129-137

Kühnhold V, Kiewnick S \& Sikora R (2006). Development of an in vitro bioassay to identify sugar beet resistance to the stem nematode Ditylenchus dipsaci. Nematology 8(5): 641-645

Mennan S (2005). Soğan Sak Nematodu (Ditylenchus dipsaci) (Kuhn, 1857) (Tylenchida: Anguinidae)'nun soğan (Allium cepa)'daki zararına, ekim zamanı ve populasyon yoğunluğunun etkileri. Türkiye Entomoloji Dergisi 29: 215-224

Mwaura P, Niere B \& Vidal S (2015). Resistance and tolerance of potato varieties to patato rot nematode (Ditylenchus destructor) and stem nematode (Ditylenchus dipsaci). Annals of Applied Biology 166: $257-270$ 
Ogbuji R O (1979). A study of the effects of Ditylenchus dipsaci on three onion cultivars with different skin color in Nigeria. Journal of Agriculture in the Tropics and Subtropics 80: 151-155

Pang W, Hafez S L \& Sundararaj P (2009). Screening of onion cultivars for reistance and tolerance to Prtylenchus penetrans and Meloidogyne hapla. Nematropica 39(1): 47-55

Plowright RA, Caubel G \& Mizen KA(2002). Ditylenchus species. In: Starr J L, Cook R \& Bridge J (Eds.), Plant resistance to parasitic nematodes, CABI Publishing, Wallingford, pp. 107-139

Sikora A R \& Fernandez E (2005). Nematode parasites of vegetables, In: Luc M, Sikora R A \& Bridge J (Eds.), Plant Parasitic Nematodes in Subtropical and Tropical Agriculture, CABI Publishing, UK, pp. 319393
Sturhan D \& Brzeski M W (1991). Stem and Bulb Nematodes, Ditylenchus spp., In: Nickle W R (Ed.), Manual of Agricultural Nematology, Marcel Dekker Publications, New York, pp. 423-465

Toynbee-Clarke G \& Bond D A (1970). A laboratory technique for testing red clover seedlings for resistance to stem eelworm (Ditylenchus dipsaci). Plant Pathology 19: 173-176

Trudgill D L (1991). Resistance to and tolerance of plant parasitic nematodes in plants. Annual Review of Phytopathology 29: 167-192

Yavuzaslanoglu E, Dikici A \& Elekcioglu I H (2015). Effect of Ditylenchus dipsaci Kühn, 1857 (Tylenchida: Anguinidae) on onion yield in Karaman Province, Turkey. Turkish Journal of Agriculture and Forestry 39: 227-233 